Limnological Review (2013) 13, 3: 163-169

DOI 10.2478/limre-2013-0018

\title{
Metal accumulation in sediments and biota in Malta Reservoir (Poland)
}

\author{
Piotr Rzymski ${ }^{1}$, Piotr Klimaszyk ${ }^{2}$, Przemysław Niedzielski ${ }^{3}$, Barbara Poniedziałek ${ }^{1}$ \\ ${ }^{1}$ Department of Biology and Environmental Protection, Poznan University of Medical Sciences, Rokietnicka 8, 60-806 Poznań, Poland, \\ e-mail: rzymskipiotr@ump.edu.pl (corresponding author) \\ ${ }^{2}$ Department of Water Protection, Adam Mickiewicz University, Umultowska 89B, 61-614 Poznań, Poland, e-mail: pklim@amu.edu.pl \\ ${ }^{3}$ Department of Water and Soil Analysis, Adam Mickiewicz University, Umultowska 89, 61-614 Poznań, Poland
}

\begin{abstract}
Municipal water reservoirs improve urban landscape architecture, providing water for various domestic uses. At the same time, they are under strong human impact affecting water quality and biological conditions. We investigated the level of metal accumulation ( $\mathrm{Cd}, \mathrm{Co}, \mathrm{Cr}, \mathrm{Cu}, \mathrm{Fe}, \mathrm{Ni}, \mathrm{Mn}, \mathrm{Pb}$ and $\mathrm{Zn}$ ) in sediments as well as mussels Anodonta anatina and Unio tumidus and common reed Phragmites australis collected from 8 sampling sites at Malta Reservoir (Poznań, Poland) just before the complete drainage of the lake in November, 2012. In all investigated samples metal concentrations ranked in decreasing order: $\mathrm{Fe}>\mathrm{Mn}>\mathrm{Zn}>\mathrm{Cu}>\mathrm{Cr}>\mathrm{Ni}>\mathrm{Pb}>\mathrm{Co}>\mathrm{Cd}$. Accumulation of toxic metals in roots of $P$. australis was higher than in soft tissues of mussels although it did not exceed phytotoxic levels. Roots of P. australis accumulated high levels of $\mathrm{Cr}$ (mean $9.7 \mu \mathrm{g} \mathrm{g}^{-1}$ ) and $\mathrm{Ni}$ (mean $5.7 \mu \mathrm{g} \mathrm{g}^{-1}$ ). U. tumidus accumulated higher concentrations of $\mathrm{Cr}$ (mean $1.1 \mu \mathrm{g} \mathrm{g}^{-1}$ ) than A. anatina indicating potential use in bioindication of this metal. The present study provides the most recent information on metal content in sediments and biota in Malta Reservoir and, further, suggests that this reservoir is capable of accumulating toxic elements from preceding water bodies (Lake Swarzędz) and surrounding residential areas.
\end{abstract}

Key words: heavy metals, bioaccumulation, Phragmites australis, unionids, Metal Pollution Index

\section{Introduction}

Artificial reservoirs have been constructed since antiquity for water storage purposes. Now, reservoirs improve urban landscape architecture, providing water for various municipal, agricultural and industrial uses, generation of hydroelectricity or sport and recreation activities (Kajak 1998). Simultaneously, they are under strong human impact affecting water quality and biological conditions. Air and urban area surface pollution, erosion processes within non-urbanized areas, direct sewage discharges or pollution of tributaries are the main sources of various contaminants including metals in water reservoirs situated near urban settlements (Osmulska-Mróz 1992; Bajkiewicz-Grabowska 2004).

In relation to their biological meaning, metals can be divided into two opposite groups: essential and non-essential for living organisms. The first group is constituted of elements that play a specific metabolic role in living organisms, necessary for their normal growth and development. This group includes some elements usually classified under the term 'heavy metals', including copper $(\mathrm{Cu})$, iron $(\mathrm{Fe})$, manganese $(\mathrm{Mn})$ and zinc $(\mathrm{Zn})$, alkali metals including sodium $(\mathrm{Na})$ and potassium $(\mathrm{K})$ as well as alkaline earth metals including magnesium $(\mathrm{Mg})$ and calcium $(\mathrm{Ca})$. Although these elements are necessary for growth and development of living organisms, they can act similarly to toxic agents if their environmental availability is elevated. The second group, the non-essential metals, is constituted mainly by heavy metals: cadmium $(\mathrm{Cd})$, chromium $(\mathrm{Cr})$, cobalt $(\mathrm{Co})$, nickel $(\mathrm{Ni})$ and lead $(\mathrm{Pb})$. Both groups of metals are present in the environment, partially due to natural processes (e.g. geological weathering, biogeochemical cycles), but it is human activity that largely contributed to their wide distribution, contamination and toxicity. This associates heavy metals with anthropogenic sources, including agricultural activities, residential and industrial products (Szyczewski et al. 2009; Singh et al. 2011). 
It is generally accepted that toxic metals are a widespread problem in aquatic environments. Under natural conditions they are resistant to decomposition and can be accumulated in microorganisms, aquatic flora and fauna which, in turn, may enter into the terrestrial food chains (including human) resulting in further contamination of biota (Järup 2003; Milošković et al. 2013). Furthermore, they can induce a variety of toxic effects in aquatic biota resulting in, inter alia, limited growth. Therefore, monitoring of heavy metals in the environment is essential for the safeguard of biota and humans and for the protection of water quality in freshwater.

For this reason, we investigated the level of metal contamination in Malta Reservoir, the artificial water body which is situated in the city of Poznan (Poland) and is recognized nowadays as one of the most beautiful recreational reservoir in Europe.

Because levels of metals in water are usually low, ranging from milligrams per litre (ppm) to micrograms per litre (ppb), their concentration highly depends on various environmental factors (e.g. temperature, oxygen), thus we decided to investigate metals in sediments in which they are largely deposited. We also aimed to investigate the level of metal bioaccumulation in soft tissues collected from two dominant bivalve species - Anodonta anatina and Unio tumidus as well as the emerged macrophyte Phragmites australis. All studied organisms were in contact with bottom sediments, hence, it was expected that they could potentially serve as bioindicators of sediment pollution. In the present study, we also applied the Metal Pollution Index (MPI) in order to describe differences between sampling sites.

\section{Study site}

Malta Reservoir is an artificial water body built in 1952 for recreation and sports purposes. It accumulates water of the lower course of the River Cybina (right tributary of the River Warta). It is considered as one of the prettiest regatta courses in Europe with national and international canoeing and rowing competitions organized every summer. It is also used as a bathing area for city residents while its surroundings are used for various recreation activities. Malta Reservoir is a shallow (mean depth of $3 \mathrm{~m}$, maximum depth of $5 \mathrm{~m}$ ) and small (area $64 \mathrm{ha}$ ) water body with an approximate volume of $2.1 \mathrm{hm}^{3}$. Mean water residence time is 34 days. Its whole water column is mixed well by western winds, which are prevailing in this region (Joniak et al. 2000; Joniak et al. 2003). In the western part of the reservoir, the River Cybina flows into the lake and supplies it with water enriched with nitrates and phosphates that stimulate primary production of phytoplankton in Malta Reservoir (Kozak and Gołdyn 2004; Gołdyn and Szeląg-Wasielewska 2005). Cyanobacteria are the dominant group in Malta Reservoir during summer with high abundance of Aphanizomenon flos-aquae (Kozak 2006).

The catchment area of the River Cybina is dominated by cultivated fields. Before the river flows into Malta Reservoir, first it flows through Lake Swarzędz (surface $93.7 \mathrm{ha}$ ) and four small man-made reservoirs - Antoninek, Młyński, Browarny, and Olszak. Their surfaces are 7.2, 9.2, 7.1 and 3.3 ha, respectively, the mean water residence times are $0.5,1.7,1.4$ and 0.6 days, respectively, and their maximum depths are $0.8,2.3,2.2$ and $1.8 \mathrm{~m}$, respectively (Gramowska et al. 2010).

The nearby surroundings of Malta Reservoir are mainly constituted of residential areas, roads with high traffic intensity and numerous recreation and sports facilities (Fig. 1).

\section{Material and methods}

Samples of bottom sediments, bivalves Anodonta anatina (Linnaeus, 1758) and Unio tumidus (L., 1758), and the common reed Phragmites australis (Cav.) Trin. ex Steud. were collected from 8 sites at Malta Reservoir (Fig. 1). Three sites were situated in the southern part of the reservoir (M1-M3), three in the northern part (M4-M6) and two in the western part (M7-M8). All samples ( $\mathrm{n}=24$ for each investigated compartment) were collected just before the complete drainage of the lake in November, 2012.

Sediments were collected using a core sampler (diameter of $5 \mathrm{~cm}$ and length of $1 \mathrm{~m}$ ). Only the surface layer of the sediment, approximately $5 \mathrm{~cm}$ thick, was collected for analysis. The sediment was placed in a plastic container and transported to the laboratory in cold storage. The sediment was passed through a 500 $\mu \mathrm{m}$ nylon sieve to remove plant debris, sand, stones and other impurities. The resulting sediment fraction was dried for $2 \mathrm{~h}$ at $105^{\circ} \mathrm{C}$ and placed in $120 \mathrm{ml}$ plastic containers for further mineralization. Bivalve specimens were collected manually, placed in a plastic container washed with water from the given sites of the reservoir and transported to the laboratory. In the case of bivalves, fifteen individuals of each spe- 


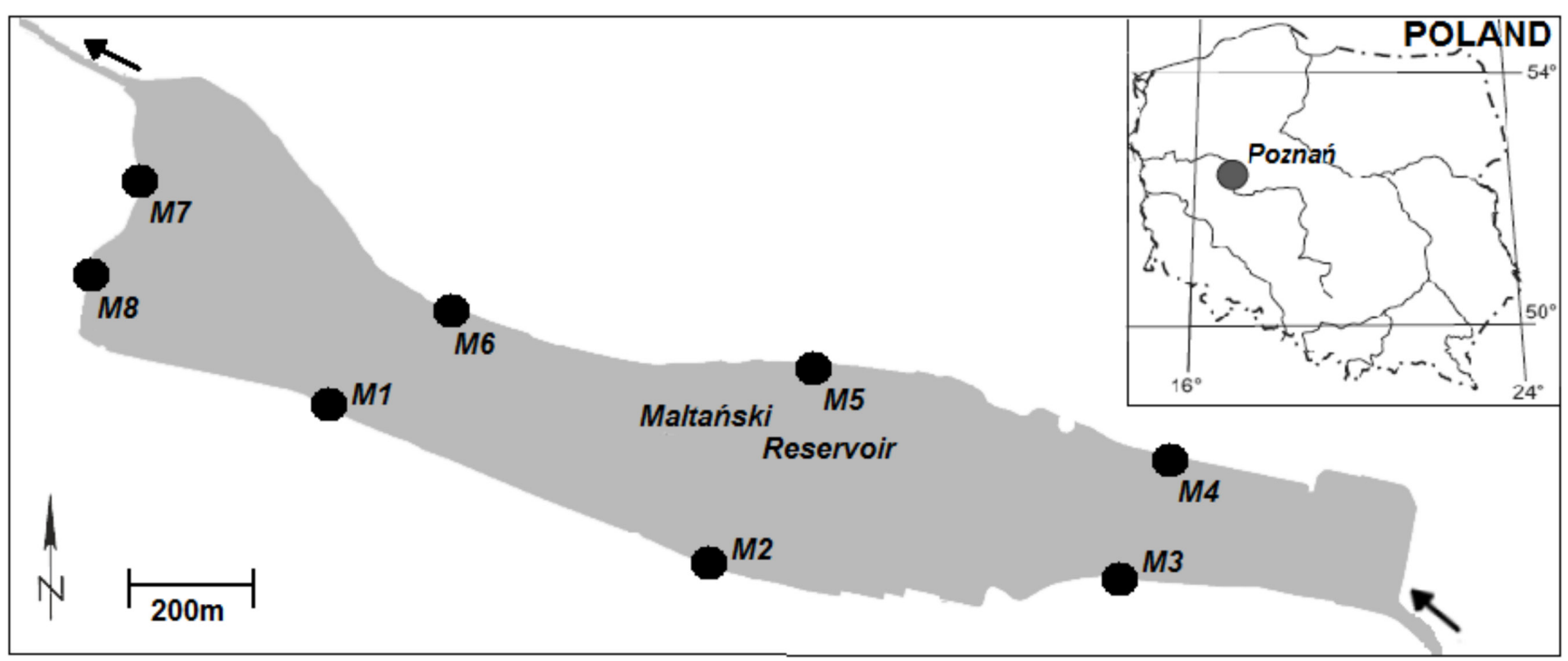

Fig. 1. Map of Malta Reservoir, showing the relative location of each sampling site

cies were collected from each sampling site. Only the largest individuals were collected. Mean shell length was $7.23 \pm 0.87 \mathrm{~cm}$ for A. anatina and $6.42 \pm 1.02 \mathrm{~cm}$ for $U$. tumidus. Mussels were kept in the laboratory in continuously aerated deionized water without food for several days to allow them to defecate. To prevent contamination before the shells were shucked, the external surface was thoroughly cleaned with a brush and water to remove all sand and periphyton adhering to the shell. All bivalves were dissected and the soft tissues were stored immediately at $-20^{\circ} \mathrm{C}$. After thawing at room temperature and rinsing six times with deionized water, soft tissues were dried to a constant weight for $24 \mathrm{~h}$ at $80^{\circ} \mathrm{C}$. Dried samples were weighed, homogenized by grinding in a porcelain mortar and stored in plastic containers washed with suprapure $\mathrm{HNO}_{3}$ for further mineralization.

$P$. australis samples were collected manually. From each site at Malta Reservoir, 5-6 samples of $P$. australis were collected within a $5 \times 2 \mathrm{~m}$ plot and placed in a plastic bag. In the laboratory, roots were washed thoroughly in deionized water to remove sediments and periphyton, and dried to a constant weight at $80^{\circ} \mathrm{C}$ for further mineralization. Samples of sediments, bivalve soft tissues and $P$. australis were mineralized prior to the analysis of metal concentration. A total of $2.0 \pm 0.1 \mathrm{~g}$ of sediment from each sample was placed in a conical flask and carefully washed with $20 \mathrm{ml}$ of suprapure $\mathrm{HNO}_{3}$. Connected to a reflux condenser, the flask was constantly heated at $80^{\circ} \mathrm{C}$ for 30 minutes. After cooling, the contents of the flask were filtered, using a cellulose filter (Whatman, UK), into a polypropylene tube for analysis of metal concentration. A similar mineralization procedure was conducted for samples with $P$. australis roots and leaves. Bivalve samples were kept for 14 days in containers flushed with $\mathrm{HNO}_{3}(14$ $\mathrm{mol} \mathrm{dm} \mathrm{d}^{-3}$ ), and their contents were transferred to conical flasks and further prepared for metal concentration analysis as described for sediments and $P$. australis samples.

Metal concentration was determined using flame atomic absorption spectrometry (SpectrAA 220FS; Varian, Australia). Argon was used as a carrier gas. The following wavelengths were applied: $\mathrm{Cd}$ - $228.8 \mathrm{~nm} ; \mathrm{Co}-240.7 \mathrm{~nm} ; \mathrm{Cr}-357.9 \mathrm{~nm} ; \mathrm{Cu}-324.8$ $\mathrm{nm} ; \mathrm{Fe}-248.3 \mathrm{~nm} ; \mathrm{Mn}-279.5 \mathrm{~nm} ; \mathrm{Ni}-232.0 ; \mathrm{Pb}$ - $217.0 \mathrm{~nm} ; \mathrm{Zn}-213.9 \mathrm{~nm}$. The calibration was performed using standard analytical solutions (Merck, Germany). The limits of metal detection were $0.01 \mathrm{mg}$ $\mathrm{dm}^{-3}$ for water samples and $0.01 \mathrm{mg} \mathrm{kg}^{-1}$ for sediments, bivalve and $P$. australis samples.

To compare the total content of metals in soft tissues of bivalves and P. australis at the different sampling sites, the metal pollution index (MPI) was used, obtained according to the equation (Usero et al. 1997): MPI $=\left(\mathrm{Cf}_{1} \times \mathrm{Cf}_{2} \ldots \mathrm{Cf}_{n}\right)^{1 / n}$, sample.

where: $\mathrm{Cf}_{\mathrm{n}}$ is the concentration of metal $\mathrm{n}$ in the

The correlations were calculated using Spearman's rank correlation coefficient. In order to compare two independent groups of variables the Mann Whitney U test was used. 


\section{Results}

All the studied metals were found in both sediments and biological samples. Essential metals were a dominant group in Malta Reservoir. The general rank of metal concentrations demonstrated the decreasing order of $\mathrm{Fe}>\mathrm{Mn}>\mathrm{Zn}>\mathrm{Cu}>\mathrm{Cr}>\mathrm{Ni}>\mathrm{Pb}>\mathrm{Co}>\mathrm{Cd}$. The highest metal concentrations, both essential and non-essential, were noted in sediments and $P$. australis roots (Table 1).

Levels of $\mathrm{Co}, \mathrm{Cr}, \mathrm{Mn}$, and $\mathrm{Ni}$ found in roots of $P$. australis exceeded the ones observed in sediments. The concentration of Co in roots was over twice as great as in sediments. On the other hand, the concentration of essential Fe was lower in plant roots as compared with those found in sediments.

Statistically significant correlations $(\mathrm{p}<0.05)$ between metal content in sediments and roots were observed for $\mathrm{Cd}(\mathrm{Rs}=0.37), \mathrm{Cr}(\mathrm{Rs}=0.59), \mathrm{Cu}(\mathrm{R} s=0.89)$, $\mathrm{Ni}(\mathrm{Rs}=0.96)$ and $\mathrm{Pb}(\mathrm{Rs}=0.35)$. These correlations indicated a high correspondence of deposition of metals in sediments and their uptake by P. australis roots.

On the other hand, metal content found in bivalve tissues was generally low and did not exceed that observed in sediments (Table 1). For non-essential metals, only $\mathrm{Cr}$ showed an accumulation of more than $1 \mathrm{mg} \mathrm{kg}^{-1}$ in $U$. tumidus, over 3 -fold higher than the concentration of $\mathrm{Cr}$ found in A. anatina. This difference was statistically significant (Mann Whitney $\mathrm{U}, \mathrm{p}<0.05)$. A. anatina, however, accumulated a great amount of essential metals with mean concentrations of $\mathrm{Mn}$ and $\mathrm{Fe}$ over $10 \mathrm{mg} \mathrm{kg}^{-1}$ higher than those in $U$. tumidus and mean concentrations of $\mathrm{Cu}$ over $4.5 \mathrm{mg}$ $\mathrm{kg}^{-1}$ higher than in U. tumidus. All of these three differences were statistically significant (Mann Whitney $\mathrm{U}, \mathrm{p}<0.05)$.

Despite the low metal concentrations found in A. anatina and $U$. tumidus, few significant and positive correlations were found between the content of elements in soft tissues and their associated sediments. In $U$. tumidus, $\mathrm{Cr}$ and $\mathrm{Pb}$ content was correlated with sediments ( $\mathrm{Rs}=0.59$ for both, $\mathrm{p}<0.05)$ while in $A$. anatina the correlation with sediments was found for $\mathrm{Ni}$ $(\mathrm{Rs}=0.59, \mathrm{p}<0.05)$ and $\mathrm{Pb}(\mathrm{Rs}=0.60, \mathrm{p}<0.05)$.

Significant differences in metal concentration between sampling sites were observed, as revealed by the MPI values (Table 2). Regardless of the investigated type of sample, the lesser metal pollution was

Table 1. Mean $( \pm S D)$ metal concentrations found in investigated samples ( $n=24$ for each investigated compartment)

\begin{tabular}{lcccc}
\hline & Sediment & A. anatina & U. tumidus & P. australis \\
\hline $\mathrm{Cd}$ & $0.09 \pm 0.01$ & $0.04 \pm 0.03$ & $0.04 \pm 0.02$ & $0.08 \pm 0.03$ \\
\hline $\mathrm{Co}$ & $0.31 \pm 0.17$ & $0.18 \pm 0.09$ & $0.18 \pm 0.07$ & $0.65 \pm 0.28$ \\
\hline $\mathrm{Cr}$ & $7.8 \pm 2.2$ & $0.33 \pm 0.17$ & $1.11 \pm 0.71$ & $9.7 \pm 5.0$ \\
\hline $\mathrm{Cu}$ & $11 \pm 4$ & $9.33 \pm 1.12$ & $4.59 \pm 2.43$ & $12 \pm 5$ \\
\hline $\mathrm{Fe}$ & $4460 \pm 850$ & $78.3 \pm 15.1$ & $66.8 \pm 23.1$ & $2080 \pm 1200$ \\
\hline $\mathrm{Mn}$ & $693 \pm 255$ & $29.3 \pm 8.02$ & $19.1 \pm 6.0$ & $961 \pm 552$ \\
\hline $\mathrm{Ni}$ & $4.2 \pm 0.5$ & $0.06 \pm 0.04$ & $0.77 \pm 0.09$ & $5.7 \pm 1.7$ \\
\hline $\mathrm{Pb}$ & $2.7 \pm 1.3$ & $0.15 \pm 0.07$ & $0.21 \pm 0.11$ & $1.6 \pm 1.1$ \\
\hline $\mathrm{Zn}$ & $72 \pm 19$ & $42.2 \pm 11.4$ & $51.3 \pm 25.2$ & $72 \pm 36$ \\
\hline
\end{tabular}

Table 2. Mean Metal Pollution Index calculated for each sampling site

\begin{tabular}{|c|c|c|c|c|c|}
\hline \multirow{2}{*}{ Site } & \multirow{2}{*}{ Orientation } & \multicolumn{4}{|c|}{ MPI } \\
\hline & & Bottom sediments & A. anatina & U. tumidus & P. australis \\
\hline M1 & South & 9.7 & 1.4 & 1.9 & 11.9 \\
\hline M2 & South & 12.3 & 1.5 & 1.9 & 12.5 \\
\hline M3 & South & 14.3 & 1.8 & 2.6 & 13.6 \\
\hline M4 & North & 11.1 & 1.4 & 0.6 & 4.8 \\
\hline M5 & North & 10.9 & 0.9 & 0.6 & 5.6 \\
\hline M6 & North & 12.0 & 0.7 & 0.9 & 4.8 \\
\hline M7 & West & 15.4 & 1.6 & 1.6 & 15.4 \\
\hline M8 & West & 15.0 & 2.0 & 2.0 & 17.5 \\
\hline
\end{tabular}


always found at sites situated in the northern part of the reservoir (M4-M6). For sediments, the highest MPI was found at the western sampling sites (M7 and M8). A similar tendency was also observed in MPI calculated for roots of $P$. australis. Mean MPI for plants overgrowing western sites was 16.5 , higher by $69.1 \%$ as compared with the mean MPI calculated for plants overgrowing northern sites, and by $23.1 \%$ as compared with the mean MPI found at southern sites. Calculated MPI for A. anatina and U. tumidus tissues also revealed the lowest values for specimens collected at the northern site of Malta Reservoir. There was, however, no clear difference between MPI values calculated for bivalve samples collected at the southern and western sites.

\section{Discussion}

As indicated by Gołdyn et al. (2001), Malta Reservoir could be considered as a site where nutrients transported by the River Cybina sink. Later Komorowicz et al. (2010) and Gramowska et al. (2010) demonstrated that the reservoir water is also characterized by some relevant levels of metal, including non-essential, toxic ones. Their concentration followed a decreasing order which was found in our study in both sediments and biological samples. The same authors also found that water from Lake Swarzędz is characterized by significantly higher metal concentrations (Komorowicz et al. 2010; Gramowska et al. 2010). It can be hypothesized that Lake Swarzędz plays a relevant role in the contamination of Malta Reservoir. Until 1991 municipal and industrial sewage was discharged directly into Lake Swarzędz (Gołdyn and Grabia 1998). After implementation of the urban sewage system, many buildings still had illegal connections with a nearby ditch or with the rain drainage system while storm water was not collected or treated until 2002 (Gołdyn and Grabia 1998; Kowalczewska-Madura and Gołdyn 2003). The lake remains degraded and hypertrophic with anoxia observed at the bottom during the summer season (Kowalczewska-Madura and Gołdyn 2006). Such conditions promote the formation of soluble and toxic forms of metals including $\mathrm{Cr}$ (Berry et al. 2004) and Ni (Shine et al. 1998) which are released from sediments to the water column. These two elements $(\mathrm{Cr}$ and $\mathrm{Ni}$ ) are the main ingredients of furniture and decorative paints and lacquers, which are heavily produced in the town of Swarzędz. We indicate here that Lake Swarzędz is possibly the primary source of toxic metals (such as $\mathrm{Cr}$ and $\mathrm{Ni}$ ) for Malta Reservoir. However the leakage of metals from Lake Swarzędz and their transport through the River Cybina requires further investigations.

The other source of metals for Malta Reservoir includes the urban surroundings of the water body residential areas and roads with high traffic intensity. This is strongly supported by the significantly higher MPI values found for sediment and biological samples collected at the western and southern sites of Malta Reservoir, which are under stronger impact of human activity. It has been shown that urban runoff may be a source of various chemical compounds, including metals, and can contribute to the contamination of aquatic environments and their biota, including mussels and aquatic plants (Gillis 2012; Zgheib et al. 2012).

Metals deposited in the water environment can enter the food chain usually through their uptake by phytoplankton and aquatic plants. It has been demonstrated that in numerous aquatic plants such as Typha australis, Najas marina, Nuphar lutea, Potamogeton lucens, Potamogeton nodosus or Scripus maritimus, as well as $P$. australis, metals are largely retained in roots and translocated to aboveground parts only in small quantities (Duman et al. 2007; Mazej and Germ 2009; Alhashemi et al. 2011). Our study is consistent with these findings and further demonstrates that metal accumulation can exceed background levels (found in sediments). This was particularly clear for $\mathrm{Co}, \mathrm{Cr}, \mathrm{Cu}$, $\mathrm{Mn}, \mathrm{Ni}$ and $\mathrm{Zn}$. Thus we can speculate that $P$. australis, which is the dominant emerged macrophyte in Malta Reservoir, could play an important role in inactivation of metals deposited in this water body. Partial removal of $P$. australis conducted every 4 years during reservoir restoration can contribute to a decrease in metal content and bioavailability. Interestingly, accumulation of $\mathrm{Fe}$ in roots was very low. This metal, however, is essential and takes part in metabolic processes, thus its transport to other plant organs (e.g. leaves) is obviously expected to occur and vary depending on demand.

We have found that the level of metal accumulation in the soft tissues of $A$. anatina and U. tumidus was low as compared with concentrations observed in roots of P. australis. In no case did metal content exceed that found in associated sediments. Contrary to our findings, other studies reported a high level of metal accumulation in unionids including species from both the Anodonta and Unio genus (Gundacker 2000; Liu et al. 2010). However, our results reflect the level of metal accumulation that occurred during a short 
period of time (4 years), since the last restoration in 2008 when the reservoir was completely drained and emerged plants and sediments were removed. Our study indicates that metals in Malta Reservoir did not largely enter the lower trophic levels for mussels but were rather deposited in sediments and later retained in roots of aquatic plants. This is supported by the fact that sediments collected from Malta Reservoir have a high proportion of mineral fraction, thus suggesting aerobic conditions in which metals are mainly insoluble in water, non-toxic to organisms and inactivated in sediments (Rybak et al. 2012).

However, in the unionid species with burrowing and suspension feeding habits, differences in $\mathrm{Cr}$ accumulation were found. U. tumidus accumulated significantly higher levels of this metal than A. anatina. This shows potential capabilities of this species to bioindicate $\mathrm{Cr}$ contamination in the aquatic environment. On the other hand, A. anatina demonstrated a higher accumulation of essential metals such as $\mathrm{Cu}, \mathrm{Mn}$ and $\mathrm{Zn}$. Demand and bioconcentration of these elements appear to be controlled by biological processes in mussels (Bordin et al. 1992; Moura et al. 2000). Cu forms hemocyanin, Fe binds to ferritin, an important detoxification protein, $\mathrm{Mn}$ is a cofactor for enzymes including manganese superoxide dismutase (MnSOD) and $\mathrm{Zn}$ is required for more than 200 metalloenzymes for maximum catalytic activity (Liu et al. 2010). A. anatina is larger than $U$. tumidus, thus its demand for essential elements appears to be higher, which could explain the interspecific differences observed in our study.

\section{Conclusion}

Runoffs from surrounding residential areas and inflows from Lake Swarzędz (through the River Cybina) appear to be the main source of metals for Malta Reservoir. However, these elements are mainly accumulated in the sediments and retained in the roots of emerged plants and, probably do not represent a threat to higher trophic levels. Studied unionids demonstrated relatively low metal bioaccumulation. Only $U$. tumidus accumulated large quantities of $\mathrm{Cr}$ indicating a potential for bioindication of this metal. Regular removal of $P$. australis conducted every 4 years could contribute to decreasing the metal concentrations in Malta Reservoir and result in a lesser contamination of the outflowing River Cybina and subsequently the River Warta.

\section{References}

Alhashemi A.S., Karbassi A.R., Kiabi B.H., Monavari S.M., Nabavi S.M., Sekhavatjou M.S., 2011, Bioaccumulation of trace elements in trophic levels of wetland plants and waterfowl birds, Biol. Trace Elem. Res. 142: 500-16.

Bajkiewicz-Grabowska E., 2004, Podatność jezior na eutrofizację (Susceptibility of lakes to eutrophication), [in:] Zdanowski B., Hutorowicz A., Białokoz W. (eds.), Ekosystemy wodne Parku Narodowego Bory Tucholskie (Water ecosystems of the Tuchola Forest National Park), IRS, Olsztyn: 17-32 (in Polish).

Berry W.J., Boothman W.S., Serbst J.R., Edwards P.A., 2004, Predicting the toxicity of chromium in sediments, Environ. Toxicol. Chem. 23: 2981-2992.

Bordin G., McCourt J., Rodriguez A., 1992, Trace metals in the marine bivalve Macoma balthica in the Westerschelde estuary (The Netherlands). Part 1: Analysis of total copper, cadmium, zinc and iron concentrations - locational and seasonal variations, Sci. Total Environ. 127: 255-280.

Duman F., Cicek M., Sezen G., 2007, Seasonal changes of metal accumulation and distribution in common club rush (Schoenoplectus lacustris) and common reed (Phragmites australis), Ecotoxicology 16: 457-63.

Gillis P.L., 2012, Cumulative impacts of urban runoff and municipal wastewater effluents on wild freshwater mussels (Lasmigona costata), Sci. Total Environ. 431: 348-56.

Gołdyn R., Grabia J. 1998. Program ochrony wód rzeki Cybiny (Protection programme of waters in the River Cybina) [manuscript], Urząd Miasta Poznania, Wydz. Ochrony Środowiska, Poznań, p. 101 (in Polish).

Gołdyn R., Szeląg-Wasielewska E., 2005, The effects of two shallow reservoirs on the phyto- and bacterioplankton of lowland river, Pol. J. Environ. Stud. 14: 437-444.

Gramowska H., Krzyzaniak I., Baralkiewicz D., Goldyn R., 2010, Environmental applications of ICP-MS for simultaneous determination of trace elements and statistical data analysis, Environ. Monit. Assess. 160: 479-490.

Gundacker C., 2000, Comparison of heavy metal bioaccumulation in freshwater mollusks of urban river habitats in Vienna, Environ. Pollut. 110: 61-67.

Järup L., 2003, Hazards of heavy metals contamination, Brit. Med. Bull. 68: 167-182.

Joniak T., Kamińska A., Gołdyn R., 2000, Influence of the wind on vertical changes of water properties in a shallow reservoir, [in:] Gurgul H. (ed.), Physicochemical problems of natural water ecology, Szczecin University Press, Szczecin: 67-75.

Joniak T., Gołdyn R., Kozak A., 2003, The primary production of phytoplankton in the restored Maltanski Reservoir in Poland, Hydrobiologia 506: 311-316.

Kajak Z., 1998, Hydrobiologia - limnologia. Ekosystemy wód śródlądowych (Hydrobiology - limnology. Freshwater ecosystems), Wyd. Nauk. PWN, Warszawa, p. 355 (in Polish). 
Komorowicz I., Gramowska H., Barałkiewicz D., 2010, Estimation of the lake water pollution by determination of 18 elements using ICP-MS method and their statistical analysis, J. Environ. Sci. Health A Tox. Hazard. Subst. Environ. Eng. 45: 348-354.

Kowalczewska-Madura K., 2003, Mass balance calculations of nitrogen and phosphorus for Swarzędzkie Lake, Limnol. Rev. 3: 113-118.

Kowalczewska-Madura K., Gołdyn R., 2006, Anthropogenic changes in water quality in the Swarzędzkie Lake (West Poland), Limnol. Rev. 6: 147-154.

Kozak A., 2006, Phytoplankton community structure in a dam reservoir in Poznań, Teka Kom. Ochr. Kszt. Środ. Przyr. 3: 76-80.

Kozak A., Gołdyn R., 2004, Zooplankton versus phyto- and bacterioplankton in the Maltański Reservoir (Poland) during an extensive biomanipulation experiment, J. Plankton Res. 26: 37-48.

Liu H., Yang J., Gan J., 2010, Trace element accumulation in bivalve mussels Anodonta woodiana from Taihu Lake, China, Arch. Environ. Contam. Toxicol. 59: 593-601.

Mazej Z., Germ M., 2009, Trace element accumulation and distribution in four aquatic macrophytes, Chemosphere 74: 642-647.

Milošković A., Branković S., Simić V., Kovačević S., Cirković M., Manojlović D., 2013, The accumulation and distribution of metals in water, sediment, aquatic macrophytes and fishes of the Gruža Reservoir, Serbia, Bull. Environ. Contam. Toxicol., Retrived from DOI 10.1007/ s00128-013-0969-8.
Moura G., Vilarinho L., Machado J., 2000, The action of Cd, $\mathrm{Cu}, \mathrm{Cr}, \mathrm{Zn}$, and $\mathrm{Pb}$ on fluid composition of Anodonta cygnea (L.): organic components, Comp. Biochem. Physiol. B Biochem. Mol. Biol. 127:105-112.

Osmulska-Mróz B., 1992, Prognozowanie i ochrona jakości wód powierzchniowych na terenach miejskich (Prediction and protection of surface water quality in urban areas), Wyd. IOŚ, Warszawa: 11-14 (in Polish).

Rybak A., Messyasz B., Łęska B., 2012, Freshwater Ulva (Chlorophyta) as a bioaccumulator of selected heavy metals $(\mathrm{Cd}, \mathrm{Ni}$ and $\mathrm{Pb}$ ) and alkaline earth metals (Ca and $\mathrm{Mg}$ ), Chemosphere 89:1066-1076.

Shine J.P., Ika R., Ford T.E., 1998, Relationship between oxygen consumption and sediment-water fluxes of heavy metals in coastal marine sediments, Environ. Toxicol. Chem. 17:2325-2337.

Singh R., Gautam N., Mishra A., Gupta R., 2011, Heavy metals and living systems: An overview, Indian J. Pharmacol. 43:246-253.

Szyczewski P., Siepak J., Niedzielski P., Sobczyński T., 2009, Research on heavy metals in Poland, Pol. J. Environ. Stud. 18:755-768.

Usero J., GonzBlez-Regalado E., Gracia I., 1997, Trace metals in the bivalve molluscs Ruditapes decussatus and $\mathrm{Ru}-$ ditapes philippinarum from the Atlantic coast of southern Spain, Environ. Int. 23: 291-298.

Zgheib S., Moilleron R., Chebbo G., 2012, Priority pollutants in urban stormwater: Part 1 - case of separate storm sewers, Water Res. 46: 6683-6692.. 